\title{
Hubungan Pengetahuan, Sikap dan Peran Ibu dengan Kesiapan Remaja Putri Menghadapi Menarche pada Siswi Kelas 4-6 di SD 3 Peuniti Kota Banda Aceh
}

\author{
Relationship between Knowledge, Attitudes and the Role of Mothers and Young \\ Women Readiness Facing Menarche for Students in Grades 4-6 at SD 3 Peuniti \\ City of Banda Aceh
}

\author{
Chairanisa Anwar*1, Rikha Febrianty $^{2}$ \\ ${ }^{1}$ Program Studi D-IV Bidan Pendidik, Fakultas Ilmu Kesehatan, Universitas Ubudiyah Indonesia, Banda Aceh, Indonesia \\ ${ }^{2}$ Program Studi D-IV Kebidanan, Politekhnik Kesehatan Kemenkes Aceh, Banda Aceh, Indonesia \\ *Korespondensi Penulis: chaira.anwar@uui.ac.id
}

\begin{abstract}
Abstrak
Menstruasi pertama merupakan puncak dari serangkaian perubahan yang terjadi pada seorang remaja putri yang sedang menginjak dewasa Remaja-remaja putri yang pengetahuannya kurang tentang menarche mengatakan akan timbul perasaan negatif seperti cemas, takut, malu dan bingung ketika menghadapi menarche (Kurniawan, 2009). Menurut Winaris (2010) wajar jika pada umumnya remaja putri menjadi risau mengenai sesuatu yang tidak biasa atau baru. Perubahan-perubahan tersebut tidak terjadi secara spontan, tetapi melalui proses yang cepat setelah menstruasi pertama. Berdasarkan data dari Riskesdas tahun 2010 kelompok umur pertama kali haid di Provinsi Aceh adalah umur 9-10 tahun 1,1\%, 11-12 tahun 19,3\%, 13-14 tahun $40,8 \%, 15-16$ tahun $19,1 \%, 19-18$ tahun $2,3 \%$ dan $19-20$ tahun $0,1 \%$. Tujuan penelitian ini untuk mengetahui hubungan pengetahuan, sikap dan peran ibu dengan kesiapan remaja putri menghadapi menarche pada siswi kelas 4-6 di SD 3 Peuniti Kota Banda Aceh Tahun 2016.
\end{abstract}

Kata kunci: pengetahuan, sikap, peran ibu, kesiapan menarche, remaja

\begin{abstract}
The first menstruation is the culmination of a series of changes that occur in a young woman who is growing up. Young women whose knowledge is lacking about menarche say negative feelings will arise such as anxiety, fear, shame and confusion when facing menarche (Kurniawan, 2009). According to Winaris (2010) it is natural that in general young women become worried about something unusual or new. These changes do not occur spontaneously, but through a quick process after the first menstruation. Based on data from Riskesdas in 2010 the first age group in Aceh Province was 9-10 years old 1.1\%, 11-12 years 19.3\%, 1314 years $40.8 \%, 15-16$ years $19.1 \%, 19-18$ years $2.3 \%$ and $19-20$ years $0.1 \%$. This research is to find out the relationship between knowledge, attitudes and the role of mothers with young women readiness facing menarche in Class 4-6 Students at SD 3 Peuniti Banda Aceh City in 2016. This type of research is analytical with a cross sectional approach. The population in this study amounted to 131 people with purposive sampling sampling technique. Data collection was carried out using the young women in grades IV and VI of SD Negeri 3
\end{abstract}


Peuniti Banda Aceh who were assisted by the teacher in charge of the elementary school. Data analysis was performed using a computer with Chi-square $(x 2)$ statistic test with $\alpha=$ 0.05

Keywords: knowledge, attitude, mother's role, menarche readiness, adolescents

\section{PENDAHULUAN}

Masa remaja merupakan suatu periode dalam lingkaran kehidupan diantara masa kanakkanak dan masa dewasa. Perubahan biologis, psikologis, lingkungan, sosial dan hukum mempengaruhi awal dan akhir masa remaja. Masa remaja masa peralihan dari masa remaja adalah suatu bagian dari proses tumbuh kembang yang berkesinambungan sejak saat konsepsi sampai mencapai dewasa (Narendra 2002). Pubertas pada perempuan dapat ditandai dengan datangnya menstruasi untuk pertama kalinya (menarce). Menstruasi atau perdarahan periodik normal uterus merupakan fungsi fisiologis yang hanya terjadi pada perempuan. Pada dasarnya menstruasi merupakan proses katabolisme dan terjadi dibawah pengaruh hormone hipofisis dan ovarium. Menstruasi biasanya terjadi pada usia 8 - 13 tahun (Benson, dkk, 2008).

Menstruasi pertama sebenarnya merupakan puncak dari serangkaian perubahan yang terjadi pada seorang remaja putri yang sedang menginjak dewasa. Seorang anak yang akan menginjak usia remaja akan mengalami pertumbuhan dan perkembangan yang sangat cepat, baik dalam ukuran bentuk tubuh, maupun psikologis dan fungsi sosial. Perubahan-perubahan tersebut tidak terjadi secara spontan, tetapi melalui proses yang cepat setelah menstruasi pertama (Djiwandono, 2008).

Menstruasi merupakan sirklus bulanan yang normal terjadi pada wanita subur. Menstruasi pertama bisa menjadi saat yang meresahkan bagi remaja putri, seringkali disertai dengan perasaan takut, cemas dan membingungkan. Perasaan semacam ini disebabkan karena kurangnya atau salahnya informasi yang didapat anak mengenai menstruasi (Djiwandono, 2008).

Menurut WHO (2009), jumlah remaja di dunia saat ini mencapai $\pm 1,2$ milyar dan satu dari lima orang di dunia ini adalah remaja. Di Asia Tenggara, jumlah remaja mencapai $\pm 18 \%$ - $25 \%$ dari seluruh populasi di daerah tersebut. Di Indonesia jumlah remaja mencapai 30\% dari total penduduk seluruhnya. Pada remaja putri terjadi sebuah peristiwa penting yang menandakan berfungsinya seluruh organ reproduksi yaitu menarche, untuk itu diharapkan remaja putri menyiapkan diri untuk menghadapinya. Remaja-remaja putri yang pengetahuannya kurang tentang menarche mengatakan bahwa timbul perasaan negatif seperti 
cemas, takut, malu dan bingung ketika menghadapi menarche (Kurniawan, 2009). Menurut Winaris (2010) wajar jika pada umumnya remaja putri menjadi risau mengenai sesuatu yang tidak biasa atau baru. Itulah sebabnya mendapatkan informasi yang benar niscaya akan bermanfaat untuk meredam kerisauan yang tidak perlu.

Biasanya anak perempuan belajar tentang menstruasi dari ibunya, tetapi sebagian ibu enggan untuk membicarakan hal ini secara terbuka karena masih banyak masyarakat yang menganggap menstruasi adalah permasalahan yang tabu. Hal inilah yang menyebabkan anak memandang menstruasi sebagai suatu masalah yang negatif. Pada sebagian remaja putri menganggap menstruasi yang dialaminya sebagai satu beban baru atau sebagai tugas baru yang tidak menyenangkan. Sebagian besar orang tua memberikan informasi tentang menstruasi dan hubungan seksual sangat sulit untuk dikomunikasikan pada anak karena masih dianggap hal yang tabu, alasan lain adalah banyak orang tua yang enggan. (Djiwandono, 2008).

Banyak reaksi negatif terhadap menstruasi bisa dihindari atau dihilangkan bila orang tua menggunakan rencana yang bijaksana dan penuh perhatian. Dengan menyiapkan anak untuk menghadapi datangya menstruasi pertama beberapa saat sebelumnya, mengusahakan bantuan medis untuk menangani efek samping fisik dan fisiologis yang mungkin timbul menjelaskan kewajaran fenomena ini, dan menunjukkan rasa bangga dan kegembiraan karena dia telah dewasa, para ibu khususnya dan ayah dapat membantu membuat kedatangan haid sebagai peristiwa yang perlu disambut (Djiwandono, 2008).

Ibu merupakan sumber informasi yang paling penting tentang masalah haid. Ibu dapat memberikan keterangan spesifik yang sederhana, misalnya seberapa sering haid terjadi, berapa lama berlangsungnya atau seberapa banyak darah yang keluar dan bagaimana cara menggunakan pembalut (Syarief. 2003).

Beberapa penelitian tentang peran orang tua dengan kesiapan menghadapi menarche pada remaja putri sudah pernah dilakukan diantaranya adalah yang dilakukan oleh Yulisatuti (2012) yang menyimpulkan bahwa peran orangtua mempunyai hubungan yang bermakna dengan kesiapan menghadapi menarche pada remaja putri $\left(X^{2}=28,798 ; p=0,000\right)$, demikian juga dengan penelitian yang dilakukan oleh Purwanti dan Jayanti (2012) yang berjudul Faktor-faktor yang mempengaruhi kesiapan anak dalam menghadapi menarche di SDB Negeri 1 Kretek Kecamatan Paguyangan Kabupaten Brebes yang menyimpulkan bahwa remaja putri lebih siap menghadapi menarche setelah mendapatkan informasi dan dukungan 
dari orang tuanya, penelitian serupa juga dilakukan oleh Khairani (2012) yang menyimpulkan bahwa komunikasi ibu dan anak memiliki hubungan positif dengan kesiapan menghadapi menstruasi pertama.

Berdasarkan data dari Riskesdas tahun 2010 kelompok umur pertama kali haid di Provinsi Aceh adalah umur 9-10 tahun 1,1\%, 11-12 tahun 19,3\%, 13-14 tahun 40,8\%, 15-16 tahun $19,1 \%, 19-18$ tahun 2,3\% dan 19-20 tahun 0,1\%.

Sekolah Dasar 3 Peuniti Kota Banda Aceh adalah salah satu sekolah dasar negeri yang ada di Kota Banda Aceh dengan jumlah siswa \pm 266 orang yang terdiri dari siswi 131 dan siswa 135 orang, berdasarkan hasil observasi awal yang peneliti lakukan terdapat $15(40,5 \%)$ dari 37 orang siswa kelas VI yang sudah mendapatkan haid pertama, dan 10\% siswi kelas V. hasil wawancara singkat dengan siswi yang sudah mendapatkan haid pertama ditemukan bahwa mereka baru mendapatkan informasi tentang haid dari ibu ketika haid tersebut datang (40\%), sebelumnya mereka mengatakan tidak mengetahui tentang haid (30\%). Mereka juga diajarkan tentang cara menggunakan pembalut oleh ibu mereka dan cara menjaga kebersihan selama haid (30\%).

Berdasarkan latar belakang tersebut maka peneliti ingin mengkaji lebih jauh tentang Hubungan Pengetahuan, Sikap dan Peran Ibu dengan Kesiapan Remaja Putri Menghadapi Menarche Pada Siswi Kelas 4-6 di SD 3 Peuniti Kota Banda Aceh Tahun 2016.

\section{METODE PENELITIAN}

Penelitian ini merupakan penelitian analitik dengan desain penelitian cross sectional. Penelitian ini dilakukan di SD Negeri 3 Peuniti Kota Banda Aceh dimulai pada bulan Juli 2016. Jumlah sampel diambil yaitu sebanyak 131 responden. Analisis data menggunakan uji statistik Chi Square Test dengan taraf kepercayaan 95\%.

\section{HASIL DAN PEMBAHASAN}

Berdasarkan penelitian yang dilaksanakan pada bulan Agustus 2016 terhadap 131 orang remaja putri di SD Negeri 3 Peuniti Kota Banda Aceh, responden mayoritas remaja kurang siap dalam menghadapi menarche yaitu sebanyak 56 responden (61.5\%).

Analisis bivariat menggunakan uji chi_square yang bertujuan untuk mengetahui hubungan variabel pengetahuan remaja, sikap, peran ibu dengan kesiapan remaja putri menghadapi menarche. Hasil analisis bivariat tersebut disajikan pada tabel 1. sebagai berikut: 
Tabel 1. Hasil Analisis Bivariat Hubungan Pengetahuan, Sikap dan Peran Ibu dengan Kesiapan Remaja Putri Menghadapi Menarche pada Siswi Kelas 4-6 di SD 3 Peuniti Kota Banda Aceh 2016

\begin{tabular}{|c|c|c|c|c|c|c|c|}
\hline \multirow[t]{2}{*}{ Variabel Independen } & \multicolumn{4}{|c|}{ Kesiapan Menghadapi Menarche } & \multicolumn{2}{|c|}{ Total } & \multirow{2}{*}{$\begin{array}{c}\text { P- } \\
\text { Value }\end{array}$} \\
\hline & Siap & $\%$ & Kurang siap & $\%$ & $\mathbf{f}$ & $\%$ & \\
\hline \multicolumn{8}{|l|}{ Pengetahuan Remaja Putri } \\
\hline Baik & 21 & 51.2 & 20 & 48.8 & 41 & 100 & 0.008 \\
\hline Kurang & 14 & 28.0 & 36 & 72.0 & 50 & 100 & \\
\hline \multicolumn{8}{|l|}{ Sikap } \\
\hline Positif & 23 & 52.3 & 21 & 47.7 & 44 & 100 & \\
\hline Negatif & 12 & 25.5 & 35 & 74.5 & 47 & 100 & 0.016 \\
\hline \multicolumn{8}{|l|}{ Peran Ibu } \\
\hline Baik & 21 & 51.2 & 20 & 48.8 & 41 & 100 & 0.040 \\
\hline Kurang & 14 & 28.0 & 36 & 72.0 & 50 & 100 & \\
\hline
\end{tabular}

\section{Pembahasan}

1. Hubungan Pengetahuan denganKesiapan Remaja Putri Menghadapi Menarche

Hasil uji statistik (uji chi-square) diperoleh nilai $\mathrm{P}=0.008(\mathrm{P}<0.05)$. Artinya hipotesa alternatif peneliti diterima yaitu ada hubungan yang bermakna antara Pengetahuan dengan kesiapan remaja putri mengahdapi menarche di SD Negeri 3 Peuniti Banda Aceh tahun 2016.

Hasil analisis hubungan terlihat bahwa responden yang siap menghadapi menarche lebih banyak dijumpai pada remaja putri yang berpengetahuan baik $(51.2 \%)$ dari pada remaja putri yang berpengetahuan kurang $(28.0 \%)$. Sementara responden yang kurang siap menghadapi menarche lebih banyak dijumpai pada remaja putri yang berpengetahuan kurang $(78.9 \%)$ dari pada remaja putri yang berpengetahuan baik $(49.1 \%)$.

Hasil penelitian ini sesuai dengan hasil penelitian Fitri (2011) yaitu terdapat hubungan bermakna antara pengetahuan dengan kesiapan remaja menghadapi menarche dengan nilai $\mathrm{P}=0.002$. Secara emosional kesiapan dalam menghadapi menstruasi, menunjukkan bahwa hampir semua perasaan subjek mengalami cemas, bingung, tegang, takut, kaget dan deg-degan atau kurang siap menghadapi menarche (Aprilani, 2007).

Penelitian yang dilakukan oleh Muriyana 2008, perasaan remaja saat mengalami menarche adalah takut, kaget, bingung, bahkan ada juga yang merasa senang. Ketidaktahuan anak tentang menstruasi dapat mengakibatkan anak sulit untuk menerima menarche. Hasil penelitian tersebut juga sesuai dengan penelitian yang dilakukan Pramatasari (2007) tentang hubungan tingkat pengetahuan remaja putri dengan kecemasan 
SMP Negeri Pakem Sleman Yogjakarta dengan hasil ada hubungan bermakna antara pengetahuan remaja putri dengan kecemasan mengahadapi menarche.

Kesiapan anak dalam menghadapi menarche dipengaruhi oleh beberapa faktor yaitu, pengetahuan anak, usia anak saat mengalami menarche, sumber informasi tentang menstruasi sebelum anak tersebut mengalami menarche, dan sikap terhadap menstruasi sebelum anak mengalami menarche (Nurngaini, 2005).

Pengetahuan tentang menstruasi di mempunyai hubungan yang sangat erat dengan kesiapan dalam menghadapi menarche. Dimana semakin tinggi pengetahuan dan pemahaman remaja putri tentang menstruasi maka akan lebih siap untuk menghadapi menstruasi pertamanya.

Asumsi peneliti bahwa menstruasi pertama sering dihayati oleh anak gadis sebagai suatu pengalaman traumatis, terkadang anak yang belum siap menghadapi menarche dikarenakan memiliki pengetahuan yang kurang sehingga akan timbul keinginan untuk menolak proses fisiologis tersebut, anak akan merasa haid sebagai sesuatu yang kejam dan mengancam, keadaan ini dapat berlanjut ke arah yang lebih negatif, dimana anak tersebut memiliki gambaran fantasi yang sangat aneh bersamaan dengan kecemasan dan ketakutan yang tidak masuk akal, dapat juga disertai dengan perasaan bersalah atau berdosa, dimana semua hal tersebut dikaitkan dengan masalah perdarahan pada organ kelamin dan proses haidnya. Tetapi berbeda bagi anak yang memiliki pengetahuan baik, dimana telah siap dalam menghadapi menarche, mereka akan merasa senang dan bangga, dikarenakan anak menganggap dirinya sudah dewasa secara biologis.

\section{Hubungan Sikap dengan Kesiapan Remaja Putri Menghadapi Menarche}

Berdasarkan hasil uji statistik (uji chi-square) diperoleh nilai $\mathrm{P}=0.016(\mathrm{P}<0.05)$. Artinya hipotesa alternatif peneliti diterima yaitu ada hubungan yang bermakna antara sikap dengan kesiapan remaja putri menghadapi menarche di SD Negeri 3 Peuniti Banda Aceh tahun 2016. Hasil analisis hubungan menunjukkan responden yang siap menghadapi menarche lebih banyak dijumpai pada remaja putri yang bersikap positif yaitu sebanyak 23 orang $(52.3 \%)$ dari pada remaja putri yang bersikap negatif yaitu 12 orang $(25.5 \%)$. Sebaliknya responden yang kurang siap menghadapi menarche lebih banyak dijumpai pada remaja putri yang bersikap negatif yaitu sebanyak 35 orang $(74.5 \%)$ dari pada remaja putri yang bersikap positif yaitu 21 orang $(47.7 \%)$. 
Hasil penelitian sesuai dengan pendapat Suryani dan Widyasih (2008) yaitu anak yang mempunyai sikap positif akan senang dan bangga karena mereka menganngap sudah dewasa secara biologis dan anak yang mempunyai sikap negatif tentang menarche akan menolak dan menganggap menarche sebagai beban baru yang tidak menyenangkan.

Jauh sebelum menstruasi tiba, anak perempuan yang normal sudah mempunyai perasaan antisipasi (daya tangkap sebelumnya) yang berbeda-beda terhadap menstruasi. Antisipasi anak ini bergantung pada informasi yang diperoleh sebelumnya. Periode antisipasi yang disebut pula sebagai periode penantian itu segera diakhiri oleh masa kematangan, dengan tibanya haid atau menstruasi. Peristiwa menstruasi pada seorang perempuan menyatakan bahwa anak perempuan kini benar-benar sudah siap secara biologis melakukan fungsi kewanitaannya (Kartono, 2009).

Maka pada periode adolesens peristiwa menstruasi mempunyai peranan psikologis yang unik, yang mempengaruhi sikap hidup anak sampai usia kedewasaannya (Kartono, 2009). Sikap terhadap menstruasi mempengaruhi pengalaman pribadi seorang anak perempuan terhadap menstruasi dan dapat merefleksikan bagaimana perasaan menjadi seorang wanita pada umumnya. Kadang kala terjadi, sikap mengenai menstruasi sangatlah negatif dikarenakan anak perempuan lebih sering melihat menstruasi sebagai suatu kutukan atau keadaan biologis yang tidak menyenangkan daripada melihat menstruasi sebagai suatu fungsi fisiologis yang normal, yang berkaitan Shainberg, \& Galliano, 2009).

Nagar dan Aimol (2010) menyatakan bahwa pengetahuan yang diperoleh remaja tentang menstruasi akan mempengaruhi persepsi remaja tentang menstruasi pertama (menarche). Jika persepsi yang dibentuk remaja tentang menstruasi pertama (menarche) positif, maka hal ini akan berpengaruh pada kesiapan remaja dalam menghadapi menstruasi pertama (menarche). Kesiapan menghadapi menstruasi pertama (menarche) adalah keadaan yang menujukkan bahwa seseorang siap untuk mencapai kematangan fisik yaitu datangnya menstruasi pertama (menarche) pada saat menginjak usia sepuluh sampai enam belas tahun yang terjadi secara periodik (pada waktu tertentu) dan siklik (berulangulang). Hal ini ditandai dengan adanya pemahaman yang mendalam tentang proses menstruasi sehingga siap menerima dan mengalami menstruasi pertama (menarche) sebagai proses yang normal.

Gunn dan Petersen menyatakan bahwa remaja putri yang memiliki sikap negatif terhadap menstruasi akan mengalami depresi dan ketidaknyamanan pada siklus menstruasi 
mereka. Remaja putri dengan sikap yang lebih positif mengenai peran gender dan seksualitas lebih sedikit mengalami sakit saat menstruasi dibandingkan dengan remaja putri yang memiliki sikap negatif terhadap menstruasi (Paludi, 2008).

Asumsi peneliti, remaja belum mendapatkan informasi benar tentang menstruasi sehingga memiliki informasi yang salah tentang menstruasi, bahkan cenderung mengkaitkan menstruasi dengan sesuatu yang negatif. Remaja biasanya tidak mengetahui tentang dasar perubahan yang terjadi pada dirinya. Oleh karena itu, jika remaja tidak diberitahu atau tidak dipersiapkan dengan baik tentang perubahan fisik dan psikologis yang terjadi pada masa puber, maka pengalaman akan adanya perubahan fisik tersebut dapat menjadi peristiwa yang traumatis. Akibatnya, remaja akan mengembangkan sikap yang kurang baik terhadap perubahan tersebut.

3. Hubungan Peran Ibu denganKesiapan Remaja Putri Menghadapi Menarche

Berdasarkan hasil uji statistik (uji chi-square) diperoleh nilai $\mathrm{P}=0.040(\mathrm{P}<0.05)$. Artinya hipotesa alternatif peneliti diterima yaitu ada hubungan yang bermakna antara peran Ibu dengan kesiapan remaja putri menghadapi menarche di SD Negeri 3 Peuniti Banda Aceh tahun 2016. Hasil analisis hubungan menunjukkan bahwa responden yang siap menghadapi menarche lebih banyak dijumpai pada remaja putri yang memiliki ibu yang berperan baik yaitu sebanyak 21 orang (51.2\%) dibandingkan remaja putri yang memiliki ibu berperan kurang yaitu 14 orang (28.0\%).

Sedangkan responden yang kurang siap menghadapi menarche lebih banyak dijumpai pada remaja putri yang memiliki ibu yang berperan kurang yaitu sebanyak 36 orang $(72.0 \%)$ dibandingkan remaja putri yang memiliki ibu berperan baik yaitu 20 orang $(48.8 \%)$.

Hasil penelitian Nagar dan Aimol (2010) tentang Pengetahuan Remaja Meghalaya (India) tentang menstruasi menunjukan bahwa 50\% pengetahuan tentang menstruasi diperoleh remaja dari teman, $36 \%$ pengetahuan tentang menstruasi diperoleh dari ibu dan 19\% diperoleh dari keluarga terdekat. Hasil penelitian ini menggambarkan adanya hambatan komunikasi antara ibu dan anak untuk membicarakan masalah seksualitas. Pendidikan seksualitas informal dalam keluarga biasanya terjalin dalam bentuk komunikasi yang hangat antara anak dan anggota keluarga lainnya. Lestari dan Purwandari (2008) selanjutnya menambahkan bahwa komunikasi yang sering dilakukan dalam keluarga 
adalah komunikasi interpersonal. Komunikasi interpersonal adalah proses pengiriman dan penerimaan pesan-pesan antara dua orang atau diantara sekelompok kecil orang-orang, dengan beberapa efek dan beberapa umpan balik seketika (De Vito, 2009).

Peran ibu sangat penting dalam proses pertumbuhan dan perkembangan anak, terutama pada masa remaja. Remaja mulai mengenal berbagai proses seksual yang sedang terjadi pada tubuh dan jiwanya pertama kali melalui ibu (Sarwono, 2008). Umumnya anak perempuan akan memberi tahu ibunya saat menstruasi pertama kali (Santrock, 2010). Sayangnya tidak semua ibu memberikan informasi yang memadai kepada putrinya. Sebagian ibu enggan membicarakan secara terbuka sampai remaja mengalami menstruasi pertama (menarche). Kondisi ini akan menimbulkan kecemasan pada anak, bahkan sering tumbuh keyakinan bahwa mentruasi pertama (menarche) adalah sesuatu yang tidak menyenangkan atau serius. Akibatnya, anak mengembangkan sikap negatif terhadap menstruasi pertama (menarche) dan melihatnya sebagai penyakit (Llewellyn, 2005).

Anak pertama kali melakukan interaksi komunikasi dalam lingkungan keluarga terutama dengan orang yang paling lekat dengannya yaitu ibu. Hubungan kelekatan (attachment) anak ke ibunya akan berlangsung sampai anak mencapai usia remaja. Peran ibu untuk membentuk kelekatan (attachment) merupakan awal pembentukan rasa percaya (trust) pada diri anak. Bowlby dalam Hendriati (2012), menyatakan bahwa integrasi sosial dapat memiliki efek langsung terhadap status kesehatan dengan mendorong promosi kesehatan dalam perubahan tingkah laku sehat yang pada akhirnya dapat mempengaruhi status kesehatan. Kesiapan menghadapi menarche merupakan suatu bentuk perilaku kesehatan yang dapat berakibat pada kesejahteraan hidup, oleh karena itu dibutuhkan peran ibu yang memadai dalam mempersiapkan seorang remaja putri untuk menghadapi menarche.

Asumsi peneliti, sudah seharusnya ibu mempunyai peran yang lebih besar dalam memberikan informasi tentang menstruasi kepada remaja dibandingkan ayah. Oleh karena itu, ibu diharapkan dapat memberikan dukungan emosi sehingga remaja merasa nyaman dan tidak takut ketika mengalami menstruasi pertama (menarche). Pengetahuan yang dapat diberikan kepada remaja tentang menstruasi pertama (menarche) dapat berupa pengetahuan tentang proses terjadinya menstruasi secara biologis, kebersihan pada saat menstruasi, dukungan emosional dan dukungan psikologis. 


\section{KESIMPULAN}

1. Terdapat hubungan yang bermakna antara pengetahuan dengan kesiapan remaja putrimenghadapi menarche di SD Negeri 3 Peuniti Banda Aceh, dimana diperoleh nilai $\mathrm{P}$ $=0.008(\mathrm{P}>0.05)$.

2. Terdapat hubungan yang bermakna antara sikap dengan kesiapan remaja putrimenghadapi menarche di SD Negeri 3 Peuniti Banda Aceh, dimana diperoleh nilai $\mathrm{P}$ $=0.016(\mathrm{P}>0.05)$.

3. Terdapat hubungan yang bermakna antara peran ibu dengan kesiapan remaja putrimenghadapi menarche di SD Negeri 3 Peuniti Banda Aceh, dimana diperoleh nilai $\mathrm{P}$ $=0.040(\mathrm{P}>0.05)$.

\section{SARAN}

1. Kepada pendidik/ guru disarankan untuk menjadi sumber utama pengetahuan siswi dengan memberikan informasi lebih akurat dan berusaha untuk lebih aktif dalam menjelaskan masalah-masalah kesehatan terutama kesehatan reproduksi remaja. Bila memungkinkan mengadakan talk show.

2. Kepada orangtua hendaknya memberikan informasi yang efektif dan memberikan waktu yang tepat dan sesuai untuk remaja putri yang akan menghadapi menarche karena akan dapat meningkatkan kesiapan mereka dalam menghadapi menarche.

3. Kepada remaja putri di SMA SD Negeri 3 Peuniti Banda Aceh agar dapat meningkatkan pengetahuan tentang menarche seperti.

4. Kepada peneliti lain untuk dapat melakukan penelitian selanjutnya tentang beberapa faktor internal yang berkaitan dengan kesiapan menghadapi menstruasi pertama (menarche) seperti akses media informasi seperti televisi, radio, koran, jurnal, majalah, rubrik konsultasi kesehatan serta dan atau akses layanan kesehatan yang disediakan oleh Puskesmas, bidan dan Rumah Sakit. Selain itu, juga disarankan untuk mempertimbangkan teknik pengambilan sampel dengan cara random agar hasil penelitian dapat digeneralisir untuk kota Banda Aceh. 


\section{DAFTAR PUSTAKA}

Aprilani, (2007). Dukungan ibu terhadap remaja putrid dalam membantu kesiapan anak dalam menghadapi menarche (Studi kualitatif pada ibu dari siswi SD Pedurungan Kidul 07 Semarang) Universitas Diponegoro Semarang. Terdapat pada http://www.fkm.undip.ac.id. Diakses tanggal 4 Desember 2010.

Azwar, (2007). Sikap Manusia Teori dan Pengukurannya, adisi 2, Yogyakarta : Pustaka Pelajar.

Benson, dkk. (2008). Buku Saku Obstetri dan Ginekologi, Edisi 9 . Jakarta:EGC.

De Vito, J. (1995). The Interpersonal Communication Book. New York: Collins.

Djiwandono. (2008). Psikologi Pendidikan. Jakarta: Gransindo

Effendi.(1998). Ilmu Komunikasi Teori dan Praktek. Bandung : PT. Remaja Rosda Karya.

Fitri, M. (2011). Efektivitas Pendidikan Seksual Dini Terhadap Kesiapan Mengahadapi Menstruasi Awal, Skripsi, Fakultas Psikologi UGM, Yogyakarta.

Friedman.(1998). Keperawatan Keluarga : Teori dan Praktik. Jakarta : EGC.

Gunadi. (2002). Ketentuan Pajak Penghasilan. Jakarta: Penerbit Salemba Empat

Hawadi.(2011). Psikologi Perkembangan Anak, Jakarta: Grasindo.

Hendriati, A. (2012). Meninjau Kembali Pentingnya Kelekatan Ibu-Anak. Jakarta: Fakultas Psikologi Atma Jaya.

Hidayat. (2005). Pengantar ilmu keperawatan anak 1., Jakarta: Salemba Medika.

Ida.(2005). Ilmu Kebidanan Penyakit Kandungan dan Keluarga Berencana Untuk Pendidikan Bidan. Jakarta: EGS.

Kartono, K. (2009). "Psikologi wanita: Mengenal gadis remaja dan wanita dewasa", Bandar Maju, Bandung.

Kurniawan.(2009). Pengaruh Pendidikan Kesehatan terhadap Tingkat Kecemasan dalam Menghadapi Menarche pada Siswi SD Negeri 1 Gayam Kabupaten Sukaharjo. Skripsi (tidak diterbitkan). Surakarta: Fakultas Psikologi Universitas Muhammadiyah Surakarta.

Lestari \& Purwandari. (2008). Kemampuan Komunikasi Ibu-Anak tentang Seksualitas Ditinjau dari Tingkat Pengetahuan Ibu. Jurnal Indigenous, Vol 6, No 1. h. 32-39. Surakarta: Fakultas Psikologi Universitas Muhammadiyah Surakarta.

Llewellyn, (2005). Dasar-Dasar Obstetri dan Ginekologi. Edisi VI. Jakarta: Hipokrates.

Maglaya. (2008). Kepeawatan Kesehatan Komunitas Teori dan Praktik dalam Keperawatan. Jakarta: Penerbit Salemba Medika

Mubayidh. (2006). Kecerdasan dan Kesehatan Emosional Anak. Jakarta. Pustaka Al-Kautsar.

Muriyana, S.D. (2008). Studi kualitatif tantang kesiapan remaja putri sekolah dasar dalam menghadapi menarche pada usia 10-12 tahun. Semarang: Universitas Muhamadiyah Semarang. 
Moersintawati.(2008). Buku Ajar I Tumbuh Kembang Anak Remaja. Jakarta: Sagung Seto.

Nagar, S. \& Aimol, R. (2010). Knowledge of Adolescent Girls Regarding Menstruation in Tribal Areas of Meghalaya. Journal. Vol. 8. No. 1. India : Department of Human Development. College of Home Science.

Narendra. (2002). Buku Ajar I Tumbuh Kembang Anak dan Remaja Edisi Pertama IDAI. Jakarta : Sagung Seto

Notoatmodjo. (2003). Pendidikan dan Perilaku Kesehatan. Jakarta: Rineka Cipta.

Notoatmodjo. (2007). Promosi Kesehatan dan Ilmu Prilaku. Jakarta: PT Rineka. Cipta.

Nurngaini, S. (2005). Kesiapan remaja putri sekolah dasar dalam menghadapi menarche dini studi kualitatif pada siswa SD Islam Al-Azhar 14 Semarang tahun 2002. Terdapat pada: http://www.fkm.undip.ac.id/data/index.php?action=4\&idx=1989. Diakses tanggal 22 Agustus 2013.

Paludi, M. A. (2008). “The psychology of women”, (2nd ed), Prentice Hall, NJ.

Santrock, J.W. (2010). Life-Span Development: Perkembangan Masa Hidup. Edisi Kelima. Jilid 2. Jakarta: Erlangga.

Satiadarma \& Waruwu.(2007). Mendidik Kecerdasan. Jakarta: Pustaka Populer Obor.

Sarwono, S.W. (2010). Psikologi remaja. Jakarta : Rajawali Pers.

Suryani, E., \& Widyasih, H. (2008). Psikologi ibu dan anak. Yogyakarta : Fitramaya. Sudjana,2005. Statistika Untuk Penelitian, Cetakan Kedua, Bandung: Alfabeta.

Syarief. (2003). Bedah Action Scipt: Menguasai Penulisan Script Macromedia Flash MX, Elex Media Komputindo, Jakarta 